\title{
Overexpression of Acyl-CoA-Binding Protein 1 (ChACBP1) From Saline-Alkali-Tolerant Chlorella sp. Enhances Stress Tolerance in Arabidopsis
}

\author{
Kun Qiao ${ }^{1,2}$, Min Wang ${ }^{3}$, Tetsuo Takano ${ }^{4}$ and Shenkui Liu ${ }^{1 *}$ \\ ${ }^{1}$ The State Key Laboratory of Subtropical Silviculture, Zhejiang Agriculture and Forestry University, Lin'an, China, ${ }^{2}$ Shenzhen \\ Key Laboratory of Marine Bioresource \& Eco-Environmental Science, Guangdong Engineering Research Center for Marine \\ Algal Biotechnology, College of Life Science and Oceanography, Shenzhen University, Shenzhen, China, ${ }^{3}$ Key Laboratory \\ of Saline-alkali Vegetation Ecology Restoration in Oil Field (SAVER), Ministry of Education, Alkali Soil Natural Environmental \\ Science Center (ASNESC), Northeast Forestry University, Harbin, China, ${ }^{4}$ Asian Natural Environment Science Center \\ (ANESC), University of Tokyo, Tokyo, Japan
}

\section{OPEN ACCESS}

Edited by:

Alejandra A. Covarrubias,

National Autonomous University

of Mexico, Mexico

Reviewed by:

Kazuo Nakashima

Japan International Research Center

for Agricultural Sciences, Japan

Wricha Tyagi,

Central Agricultural University, India

${ }^{*}$ Correspondence:

Shenkui Liu

shenkuiliu@nefu.edu.cn

Specialty section:

This article was submitted to

Plant Abiotic Stress,

a section of the journal

Frontiers in Plant Science

Received: 26 June 2018 Accepted: 14 November 2018 Published: 28 November 2018

Citation:

Qiao K, Wang M, Takano T and Liu S (2018) Overexpression

of Acyl-CoA-Binding Protein 1

(ChACBP1) From

Saline-Alkali-Tolerant Chlorella sp.

Enhances Stress Tolerance

in Arabidopsis.

Front. Plant Sci. 9:1772.

doi: 10.3389/fp/s.2018.01772
A large proportion of the world's arable land is saline-alkali land, and this is becoming an urgent environmental problem for agriculture. One approach to address this problem is to develop new varieties of stress-resistant plants through genetic engineering. The algae (Chlorella sp.) JB6, which was previously isolated from saline-alkali land, was found to exhibit strong $\mathrm{NaHCO}_{3}$ tolerance. Here, we explored saline-alkali-tolerance genes in this alga that might be useful for producing abiotic stress-resistant transgenic plants. We identified a gene encoding acyl-CoA-binding protein 1 (ACBP1) from JB6 by screening a full-length cDNA library in yeast under $\mathrm{NaHCO}_{3}$ stress. Northern blot analyses showed that the ChACBP1 mRNA levels were significantly up-regulated under abiotic stresses such as salinity, oxidation, heavy metals, and low temperature stresses. The recombinant ChACBP1 protein was found to bind phosphatidylcholine in vitro. Green fluorescent protein-labeled ChACBP1 was localized to the cytosol. Overexpression of ChACBP1 in yeast and Arabidopsis increased their resistance to high salinity, oxidation, heavy metals, and low temperature stresses. These results suggested that ChACBP1 may mediate plant abiotic stress adaptation through phospholipid metabolism. Thus, ChACBP1 may be useful to genetically improve the tolerance of plants to saline-alkali soil.

Keywords: saline-alkali-tolerant (SAT) Chlorella, acyl-CoA-binding protein 1, gene expression, stress tolerance, in vitro filter-binding, phosphatidylcholine

\section{INTRODUCTION}

Saline-alkali soil can contain different types of salts (e.g., $\mathrm{Na}_{2} \mathrm{SO}_{4}, \mathrm{NaCl}, \mathrm{NaHCO}_{3}$ ). Neutral salts $\left(\mathrm{NaCl}\right.$ and $\left.\mathrm{Na}_{2} \mathrm{SO}_{4}\right)$ and alkaline salts $\left(\mathrm{NaHCO}_{3}\right.$ and $\left.\mathrm{Na}_{2} \mathrm{CO}_{3}\right)$ are highly destructive to plants (Guo et al., 2016; Song et al., 2017). Soils rich in $\mathrm{NaHCO}_{3}$ and $\mathrm{Na}_{2} \mathrm{CO}_{3}$ are characterized by a high pH, a high exchangeable sodium percentage, a very low water-permeability range, and saturated hydraulic 
conductivity (Shi et al., 2012; Qiao et al., 2015). Such environments, which are known as "carbonate stressed" environments, are usually barren with only a few scattered plants (Qiao et al., 2015). Carbonate stress threatens the development of agriculture and livestock husbandry. Carbonate stress impairs plants in several ways by imposing ionic stress, drought stress, and oxidative stress, resulting in nutritional deficiency, metabolic disorders, and membrane damage. These changes affect plant growth and development and agricultural yield. The induction of proteins associated with lipid metabolism and lipid signaling has been proposed to be an important factor in plants' acclimation to stress conditions (Xiao and Chye, 2011).

In plants, lipids are one of the main components of biological membranes and play important roles in diverse biological processes, such as the provision of energy for cell metabolism and the maintenance of organelle integrity and composition. During lipid metabolism in plant cells, lipids, and their derivatives are transferred within or across subcellular compartments with the aid of lipid-transfer proteins or acyl-CoA-binding proteins (ACBPs) (Xiao and Chye, 2009). Arabidopsis thaliana has six ACBPs (AtACBP1-AtACBP6) with a conserved acyl-CoAbinding domain that range in size from 10 to $73 \mathrm{kDa}$ (Xiao and Chye, 2011). In vitro, ACBPs bind phospholipids such as phosphatidylcholine (PC) (Chen et al., 2008), phosphatidic acid (PA) (Du et al., 2010), phosphatidylethanolamine (PE) (Xiao et al., 2011), and lysophosphatidylcholine (lysoPC) (Gao et al., 2010). Plant ACBPs participate in several biological processes, including early embryogenesis (Chen et al., 2010) and leaf senescence (Xiao et al., 2011), and in responses to heavy metals (Xiao et al., 2008; Gao et al., 2010; Du et al., 2015), drought (Du et al., 2013), and freezing temperatures (Chen et al., 2008). A small 10-kDa ACBP has been identified in several plants including Brassica napus (Hills et al., 1994; Brown et al., 1998), A. thaliana (Engeseth et al., 1996), and agricultural crops including cotton (Gossypium hirsutum) (Reddy et al., 1996) and rice (Oryza sativa) (Suzui et al., 2006). The small ACBP has a housekeeping function in the intracellular transport of acylCoAs (Mandrupl et al., 1992) and has been well-characterized in many eukaryotic organisms (Metzner et al., 2000). In vitro, the small ACBPs of A. thaliana (AtACBP6) and Helianthus annuus (HaACBP) have been observed to bind only PCs (Chen et al., 2008; Aznar-Moreno et al., 2016). In addition to its involvement in lipid metabolism, AtACBP6 has also been reported to enhance freezing tolerance and affect jasmonate composition (Chen et al., 2008; Ye et al., 2016). Although several studies have examined the role of $\mathrm{ACBP}$ in abiotic stresses in higher plants, little is known about its role in algae.

Previously, we found a species of Chlorella, JB6, in the alkaline-saline soil of northeastern China. This alga was found to show extremely high tolerance to $\mathrm{NaHCO}_{3}$ and $\mathrm{NaCl}$ (Wang et al., 2011; Qiao et al., 2015). Therefore, it is of great significance as a genetic resource to generate transgenic stress-tolerant plants, and for studies on the responses to abiotic stresses.

In this study, we identified a gene encoding a small ACBP (ChACBP) from Chlorella (JB6) by screening its fulllength cDNA library expressed in yeast under $\mathrm{NaHCO}_{3}$ stress. We investigated $C h A C B P$ expression in response to several abiotic stresses (high salinity, oxidation, heavy metals, and low temperature). Transgenic yeast and Arabidopsis overexpressing ChACBP showed enhanced tolerance to salinity, oxidation, heavy metals, and low-temperature stresses. Filter-binding assays revealed that ChACBP interacted with lipids. These results have clarified the molecular mechanism of ChACBP and indicate that the gene encoding this protein may be useful for generating transgenic plants resistant to saline-alkali soil.

\section{MATERIALS AND METHODS}

\section{Materials}

The saline-alkali-tolerant (SAT) microalga Chlorella JB6 was isolated and screened from extremely alkaline-saline soil $(\mathrm{pH}>10)$ from the Songnen Plain $\left(46^{\circ} 27^{\prime} \mathrm{N}, 125^{\circ} 22^{\prime} \mathrm{E}\right.$, Heilongjiang Province, China) (Wang et al., 2011; Qiao et al., 2015) and was cultivated in liquid Bold's basal medium (BBM) (Bold and Wynne, 1978). The Chlorella cells were cultured at $23 \pm 1^{\circ} \mathrm{C}$ under white light $\left(40 \mu \mathrm{mol}\right.$ photons $\left.\mathrm{m}^{-1} \mathrm{~s}^{-1}\right)$ and an $16 \mathrm{~h}$ light $/ 8 \mathrm{~h}$ dark photoperiod. Total RNA was isolated from Chlorella after $100 \mathrm{mM} \mathrm{NaHCO} 3$ treatment. An In-Fusion ${ }^{\circledR}$ SMARTer ${ }^{\circledR}$ Directional cDNA Library Construction Kit (Cat. 634933, Clontech, Palo Alto, CA, United States) was used to construct the full-length cDNA library. Mixed plasmids were expressed in Saccharomyces cerevisiae InVSCI using the PEG/LiAC method. The full-length cDNA yeast library was provided by the Alkali Soil Natural Environmental Science Center (ASNESC) at Northeast Forestry University (Harbin, China).

\section{Gene Cloning and Analysis}

The Chlorella acyl-CoA-binding protein gene (ChACBP) was amplified from a cDNA library expressed in yeast under $25 \mathrm{mM}$ $\mathrm{NaHCO}_{3}$ stress. The full-length sequence of ChACBP was obtained from the NCBI website ${ }^{1}$. The open reading frame (ORF) and the predicted protein sequence were determined and analyzed using DNASTAR Lasergene v7.1 software ${ }^{2}$. Multiple sequences were aligned with Genedoc 3.0. A phylogenetic tree was constructed using the neighbor-joining (NJ) method with Mega 3.1 software.

\section{Yeast Transformation and Stress Tolerance Assays}

The cDNA fragment of ChACBP was ligated into the pYES2 vector (Invitrogen, Carlsbad, CA, United States) digested with $B a m \mathrm{HI}$ and NotI to construct the plasmid pYES2-ChACBP. This construct and the pYES2 empty vector (control) were transformed into $S$. cerevisiae (InVSCI) using the PEG/LiAC method. To check the stress tolerance of transgenic lines, yeast cells expressing the pYES2-ChACBP vectors were incubated in liquid uracil-minus medium overnight at $30^{\circ} \mathrm{C}$ (FunGenome, Beijing, China), then adjusted to an $\mathrm{OD}_{600}$ of 0.5 , and further diluted to $10^{-1}, 10^{-2}, 10^{-3}$, and $10^{-4}$ with sterile $\mathrm{H}_{2} \mathrm{O}$.

\footnotetext{
${ }^{1}$ http://www.ncbi.nlm.nih.gov

${ }^{2} \mathrm{http}: / /$ dnastar.com/t-products-lasergene.aspx
} 
Then, $4.5 \mu \mathrm{L}$ of each dilution series was spotted onto solid medium (yeast extract $20 \mathrm{~g} / \mathrm{L}$; peptone $20 \mathrm{~g} / \mathrm{L}$; galactose 20\%) supplemented with $35 \mathrm{mM} \mathrm{NaHCO} 3,0.8 \mathrm{M} \mathrm{NaCl}, 3 \mathrm{mM} \mathrm{H}_{2} \mathrm{O}_{2}$, or $8 \mathrm{mM} \mathrm{CuCl}_{2}$. The cultures were grown for $3-7$ days at $30^{\circ} \mathrm{C}$. For the low temperature treatment, diluted yeast cells spotted onto solid medium were cultured for 20 days at $10^{\circ} \mathrm{C}$.

\section{Purification of Recombinant His-Tagged ChACBP for Filter-Binding Assays}

To construct the pQE30-ChACBP expression plasmid, the $C h A C B P$ cDNA fragment was amplified from the plasmid pYES2-ChACBP using the following primers: forward: $5^{\prime}$-GGAT CCATGGGCCTCAAGGAAGAC-3' (BamHI site underlined); and reverse $5^{\prime}$-GTCGACTCAAGCGTACTTCGCCTTC-3' (SalI site underlined). The amplified fragment was inserted into the pQE30 vector (Qiagen, Hilden, Germany), which was then transformed into Escherichia coli M15 cells. The ChACBP protein was induced, ultrasonicated, and loaded onto Ni-NTA Sefinose (Qiagen). The bound fusion protein was eluted using $250 \mathrm{mM}$ imidazole (Sigma-Aldrich, St. Louis, MO, United States). Protein samples were denatured at $100^{\circ} \mathrm{C}$ for $8 \mathrm{~min}$ and then separated by SDS-PAGE. After electrophoresis, the protein products were transferred to a nylon membrane (Amersham, Little Chalfont, United Kingdom) using a Hoefer ${ }^{\mathrm{TM}}$ TE 70 semi-dry transfer unit (Amersham) for $90 \mathrm{~min}$, then blocked for $1 \mathrm{~h}$ in $1 \%$ blocking buffer (QIAexpress Anti-His HRP Conjugate kit), probed with Penta anti-(His) 6 horseradish peroxidase (HRP)-conjugate antibody (Qiagen) for $90 \mathrm{~min}$ at $25^{\circ} \mathrm{C}$, and then detected with an ECL Western Blotting Substrate kit (Abcam, Cambridge, United Kingdom) using a Luminescent Image Analyzer LAS-4000 (Fujifilm, Tokyo, Japan). Binding of ChACBP to various lipids on a nitrocellulose filter membrane was detected as described previously with minor modifications (Chen et al., 2008). Briefly, various lipids were spotted onto the membrane and incubated overnight at $25^{\circ} \mathrm{C}$ in the dark. The lipids PC, PA, 16:0-PC, 18:0-PC, and 18:1PC (total acyl carbon: double bonds) were purchased from Sigma; and phosphatidylglycerol (PG), phosphatidyl-serine (PS), $\mathrm{PE}$, and 1,2-dimyristoyl-sn-glycero-3-phosphocholine (DMPC) were purchased from Echelon Biosciences (Salt Lake City, UT, United States). The lipid-bound membrane was blocked with $1 \%$ (w/v) nonfat milk for $1 \mathrm{~h}$, and then with $2 \mu \mathrm{g} / \mathrm{mL}$ ChACBP protein for $2 \mathrm{~h}$. The membrane was incubated with the Penta anti-(His) 6 HRP antibody for $2.5 \mathrm{~h}$ at $25^{\circ} \mathrm{C}$, detected with ECL reagent, and analyzed using the LAS-4000 imager.

\section{Expression Analysis of ChACBP Under Stress Treatments}

To check the expression level of ChACBP under various abiotic stresses including high salinity, oxidation, and heavy metal stresses, Chlorella cells were grown in liquid medium supplemented with $200 \mathrm{mM} \mathrm{NaHCO}, 200 \mathrm{mM} \mathrm{NaCl}, 2 \mathrm{mM}$ $\mathrm{H}_{2} \mathrm{O}_{2}$, or $100 \mu \mathrm{M} \mathrm{CuCl}$, respectively. Low temperature stress was applied by incubating the microalga at $4^{\circ} \mathrm{C}$. Samples were collected at $0,3,6,12,24$, and $48 \mathrm{~h}$ for analysis. The concentration gradients in the stress treatments were as follows: 0, 50, 100, 200,
300 , and $400 \mathrm{mM} \mathrm{NaHCO} ; 0,50,100,150,200$, and $300 \mathrm{mM}$ $\mathrm{NaCl} ; 0,1,2,3,4$, and $5 \mathrm{mM} \mathrm{H}_{2} \mathrm{O}_{2} ; 0,50,100,200,300$, and $500 \mu \mathrm{M} \mathrm{CuCl}_{2}$; and temperatures of $24^{\circ} \mathrm{C}, 18^{\circ} \mathrm{C}, 16^{\circ} \mathrm{C}, 14^{\circ} \mathrm{C}$, $10^{\circ} \mathrm{C}$, and $4^{\circ} \mathrm{C}$. Samples were collected at $6 \mathrm{~h}$ of these treatments, and ground in liquid nitrogen with a mortar and pestle.

Total RNA was extracted using RNAiso plus (TaKaRa, Kyoto, Japan). Northern blot analysis was performed using the Digoxigenin Nucleic Acid Detection kit (Roche, Basel, Switzerland). Total RNA ( $3 \mu \mathrm{g}$ ) was separated on a $1.5 \%$ agarose gel and transferred to a Hybond-N membrane (Amersham). The $C h A C B P$ cDNA probes were obtained using the PCR Digoxigenin Probe Synthesis kit according to the manufacturer's instructions (Roche). Hybridization was performed according to standard procedures recommended by the manufacturer (Roche), and then detected using the CDP Star system with the LAS-4000 imager.

\section{Localization of ChACBP Protein in Plant Cells}

To construct the expression plasmid pBI121-ChACBP-GFP, $C h A C B P$ was amplified from the pYES2-ChACBP plasmid by PCR using the primers ChACBP-GFP-F (5'-GGATCCATGGGC CTCAAGGAAGACTTTG-3'; BamHI site underlined) and ChACBP-GFP-R (5'-GGTACCGGAGCGTACTTCGCCTTCAG CG-3'; KpnI site underlined). The PCR product was introduced into the pEGFP plasmid (Clontech) at the BamH1 and KpnI sites. Then, ChACBP-pEGFP was digested with BamHI and NotI and ligated into the pYES2 vector (Invitrogen). The plasmid pYES2-ChACBP-GFP was inserted into the $\mathrm{pBI} 121$ vector via the $B a m \mathrm{HI}$ and XhoI digestion sites to construct the plasmid pBI121ChACBP-GFP. Agrobacterium tumefaciens strain EHA105 was transformed by electroporation with either pBI121-GFP or pBI121-ChACBP-GFP. Transgenic A. tumefaciens cells were transformed into wild-type (WT) Arabidopsis (Columbia-0) by the floral dip method (Clough and Bent, 1998). Transgenic lines overexpressing pBI121-ChACBP-GFP were selected on 1/2 MS medium containing kanamycin $(40 \mu \mathrm{g} / \mathrm{mL})$ and confirmed by northern blot analysis using a ChACBP cDNA probe. Arabidopsis protoplasts were prepared by Sheen's method (Sheen, 2002). All GFP signals were detected using a laser-scanning confocal imaging system (Olympus, Tokyo, Japan).

\section{Generation of ChACBP-Overexpressing Plants}

To construct the plasmid pBI121-ChACBP, the fulllength $C h A C B P$ was amplified from pYES2-ChACBP by PCR using the primers pBI-F (5'-GGATCCATGG GCCTCAAGGAAGACTTTG-3'; BamHI site underlined) and pBI-R (5'-GTCGACTCAAGCGTACTTCGCCTTCAG-3'; SalI site underlined). The PCR product was ligated into the pBI121 plasmid (Clontech) via the BamHI and SalI sites. The construct was amplified in E. coli and then used to transform A. tumefaciens. The positive transformants were confirmed by Northern blot and Southern blot analyses using a ChACBP probe. Genomic DNA was extracted from the leaves of 12-dayold seedlings (WT, OX-2, OX-3, and OX-4) using the CTAB 


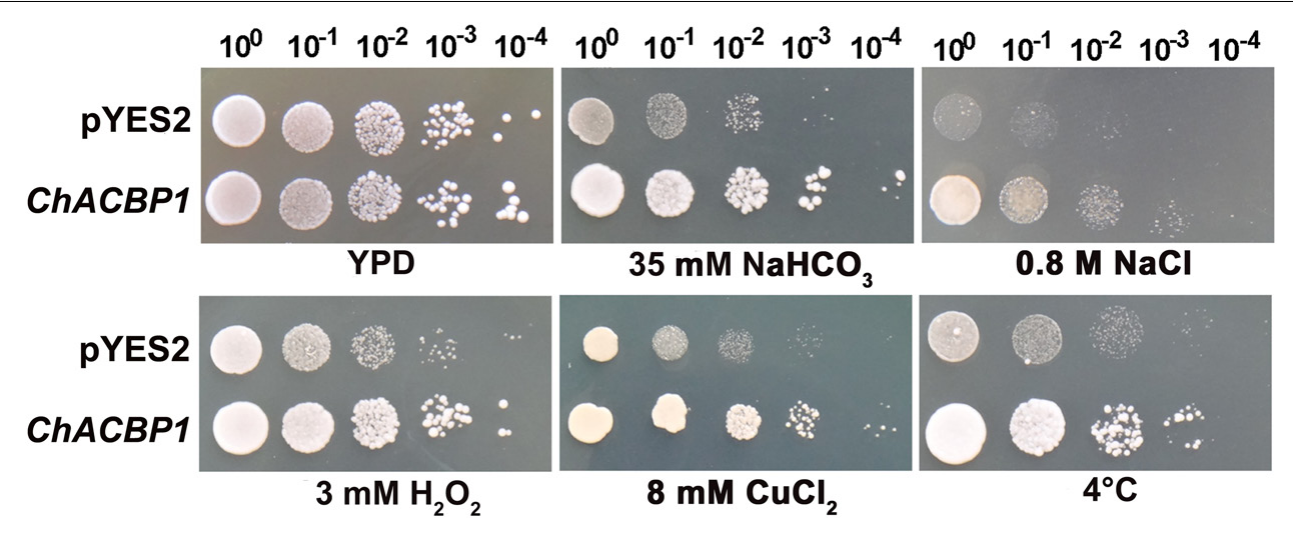

FIGURE 1 | Tolerance analysis of yeast expressing ChACBP1 to various abiotic stresses. Yeast cells containing either pYES2 empty vector or pYES2-ChACBP1 were incubated as described in Materials and Methods. Serial dilutions were spotted onto yeast extract/peptone/galactose solid plates supplemented with $\mathrm{NaHCO}_{3}$ $\mathrm{NaCl}, \mathrm{H}_{2} \mathrm{O}_{2}$, or $\mathrm{CuCl}_{2}$ at indicated concentrations. Solid yeast extract/peptone/glucose media (YPD) was the control. Growth was monitored for $3-7$ days at $30^{\circ} \mathrm{C}$. In the cold stress treatment, yeast cells were grown for 15 days at $10^{\circ} \mathrm{C}$.

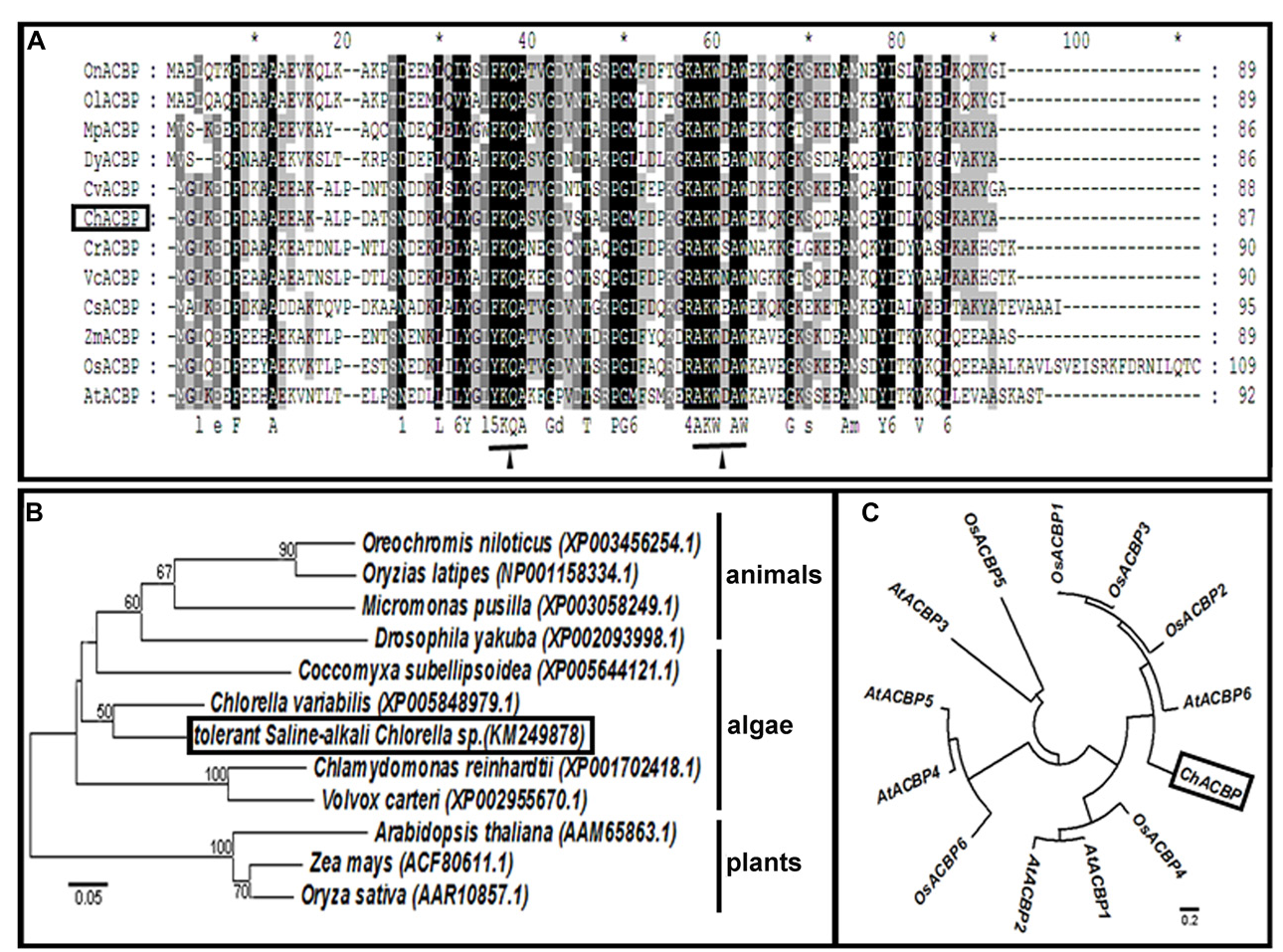

FIGURE 2 | Phylogenetic and sequence analyses of acyl-CoA-binding protein 1 (ChACBP1) from saline-alkali-tolerant Chlorella. (A) Sequence alignment of ACB domain from ChACBP1 with those of other species. YKQA and KWDAW motifs are underlined; capital letters indicate identical residues in all ACBPs; small letters indicate residues identical in most ACBPs (arrowheads). Black background indicates conserved residues. On, Oreochromis niloticus; OI, Oryzias latipes; Mp, Micromonas pusilla; Dy, Drosophila yakuba; Cv, Chlorella variabilis; Ch, Saline-alkali-tolerant Chlorella sp.; Cr, Chlamydomonas reinhardtii; Vc, Volvox carteri; Cs, Coccomyxa subellipsoidea; Zm, Zea mays; Os, Oryza sativa; At, Arabidopsis thaliana; ChACBP1 is indicated in boldface in box. (B) Neighbor-joining (NJ) phylogenetic relationships among acyl-CoA-binding protein (ChACBP) from saline-alkali-tolerant Chlorella and various ACBPs from other species. Bootstrap values were calculated 1,000 times; values $<50 \%$ are not shown. Saline-alkali-tolerant Chlorella is indicated in boldface in box. GenBank accession numbers are as follows: OnACBP (XP_003456254.1), OIACBP (NP_001158334.1), MpACBP (XP_003058249.1), DyACBP1 (XP_002093998.1), CvACBP1 (XP_005848979.1), ChACBP (KM249878), CrACBP (XP_001702418.1), VcACBP (XP_002955670.1), CsACBP (XP_005644121.1), ZmACBP (ACF80611.1), OsACBP (AAR10857.1), and AtACBP (AAM65863.1). (C) Neighbor-joining phylogenetic relationships among ChACBP and members of ACBP families in Arabidopsis thaliana and rice. Box indicates ChACBP. 


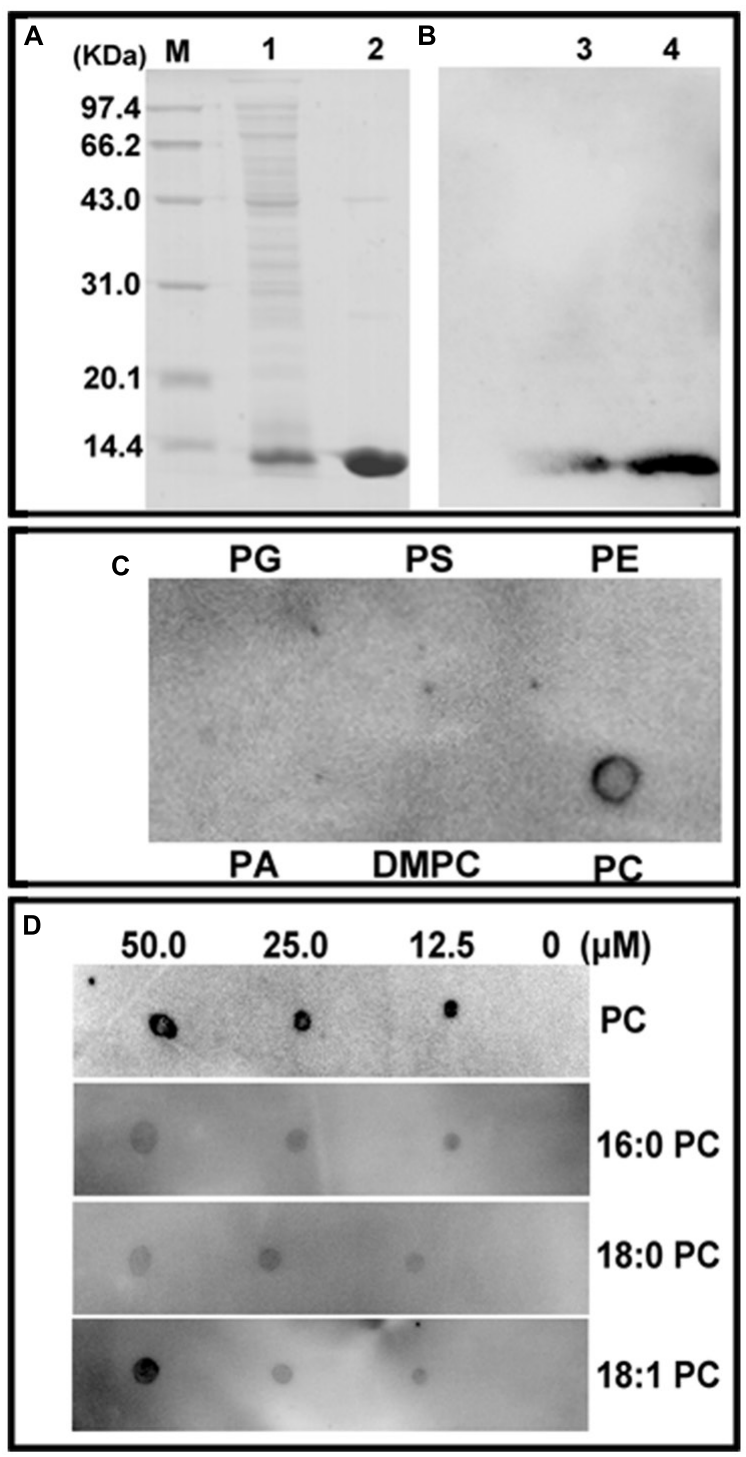

FIGURE 3 | Purification of (His) 6 -ChACBP1 recombinant protein and its interaction with phosphatidylcholine (PC). (A) Purification of ChACBP1 protein: 9.5-kDa ChACBP1 protein was purified by Ni-NTA agarose and analyzed by SDS-PAGE. M, Marker; Lane 1, pQE30-ChACBP bacterial lysate; lane 2, purified ChACBP1 protein. (B) Western blot analysis of ChACBP1: protein was transferred to nylon membrane, then probed with HRP-conjugated anti-(His) 6 antibodies. Lanes 3-4, immunoblot of (His)6-ChACBP1 fusion protein. (C) Binding of (His) $)_{6}$-ChACBP1 and lipid on filter membrane. Lipids (50.0 $\mu \mathrm{M}$ of PG, PS, PE, PA, DMPC, and PC) were spotted onto nitrocellulose and incubated with ChACBP1 protein. Binding of ChACBP1 to lipids was detected by ECL reagent with HRP-conjugated anti-(His) 6 antibodies. (D) Binding of (His) 6 -ChACBP1 to various PC acyl species. Different concentrations $(0,10,25.0$, and $50.0 \mu \mathrm{M})$ of 16:0 PC, 18:0 PC, and 18:1 PC were spotted onto nitrocellulose and incubated with ChACBP1. Binding of ChACBP1 to lipids was detected by ECL reagent.

method. The genomic DNA was digested with BamHI, and then separated by electrophoresis on a $1.5 \%$ agarose gel and blotted onto a nylon membrane. Southern blotting was conducted with the CDP Star system and analyzed using the LAS-4000 imager.

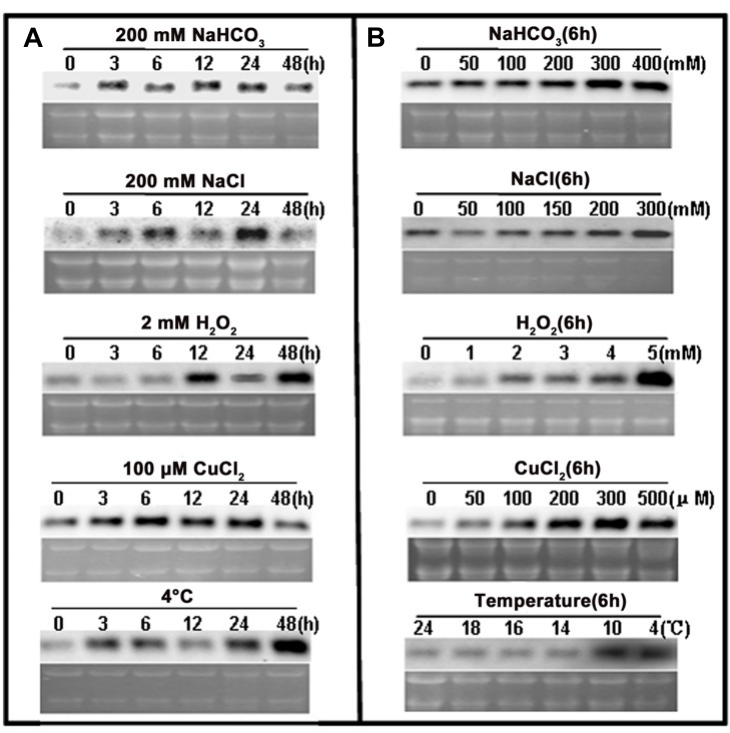

FIGURE 4 | ChACBP1 expression under abiotic stresses as detected by Northern blot analysis with digoxigenin-labeled ChACBP1 cDNA probe. (A) Northern blot analysis using total RNA $(3 \mu \mathrm{g})$ extracted from Chlorella cells treated with $200 \mathrm{mM} \mathrm{NaHCO}_{3}, 200 \mathrm{mM} \mathrm{NaCl}, 2 \mathrm{mM} \mathrm{H}_{2} \mathrm{O}_{2}, 100 \mu \mathrm{M} \mathrm{CuCl}_{2}$, or low temperature $\left(4^{\circ} \mathrm{C}\right)$ at indicated time points. (B) Northern blot analysis using total RNA $(3 \mu \mathrm{g})$ extracted from Chlorella cells treated with different concentrations of $\mathrm{NaHCO}_{3}(0,50,100,200,300$, and $400 \mathrm{mM}) ; \mathrm{NaCl}(0,50$, 100, 150, 200, and $300 \mathrm{mM}) ; \mathrm{H}_{2} \mathrm{O}_{2}(0,1,2,3,4$, and $5 \mathrm{mM}) ; \mathrm{CuCl}_{2}(0,50$, $100,200,300$, and $500 \mu \mathrm{M})$; or different temperatures $\left(24^{\circ} \mathrm{C}, 18^{\circ} \mathrm{C}, 16^{\circ} \mathrm{C}\right.$, $14^{\circ} \mathrm{C}, 10^{\circ} \mathrm{C}$, and $4^{\circ} \mathrm{C}$ ). All samples were collected at $6 \mathrm{~h}$ of treatment.

\section{Stress Tolerance of ChACBP Transgenic Plants}

The WT and transgenic Arabidopsis seeds were sterilized as described by Zhang et al. (2008). To measure root growth and fresh weight, the WT and transgenic Arabidopsis seeds were sown on $1 / 2$ MS solid agar plates supplemented with 2 and $3 \mathrm{mM}$ $\mathrm{NaHCO}_{3}, 125$, and $150 \mathrm{mM} \mathrm{NaCl}, 2$, and $3 \mathrm{mM} \mathrm{H}_{2} \mathrm{O}_{2}$, or 50 and $80 \mu \mathrm{M} \mathrm{CuCl}_{2}$. The seedlings were grown for 7-14 days at $23 \pm 1^{\circ} \mathrm{C}$ under a 8 -h light $/ 16$-h dark photoperiod. For the low temperature stress, the plates were incubated at $16^{\circ} \mathrm{C}$ and $14^{\circ} \mathrm{C}$ for 30 days. Root length and fresh weight were measured, and the mean \pm standard error were calculated from three independent experiments. Statistical analysis was performed using SPSS 13.0 software. An LSD $t$-test was used to compare the mean values among different groups $(P<0.05)$.

\section{Electrolyte Leakage}

Two-week-old seedlings of WT and three overexpressing lines were grown under $\mathrm{NaHCO}_{3}(0,1,3,5,7$, and $10 \mathrm{mM})$, $\mathrm{NaCl}(0,100,125,150,175$, and $200 \mathrm{mM}), \mathrm{H}_{2} \mathrm{O}_{2}(0,1,3$, 5, 7, and $9 \mathrm{mM}), \mathrm{CuCl}_{2}(0,20,50,80,100$, and $120 \mu \mathrm{M})$, and temperature $\left(24^{\circ} \mathrm{C}, 18^{\circ} \mathrm{C}, 16^{\circ} \mathrm{C}, 14^{\circ} \mathrm{C}, 12^{\circ} \mathrm{C}\right.$, and $\left.10^{\circ} \mathrm{C}\right)$ stress conditions for $24 \mathrm{~h}$. Seedling samples were immersed in deionized water. The solution was gently agitated at $25^{\circ} \mathrm{C}$ for $1 \mathrm{~h}$ before measuring its conductivity. The total ion content was determined after heating samples to $100^{\circ} \mathrm{C}$ for $10 \mathrm{~min}$ 

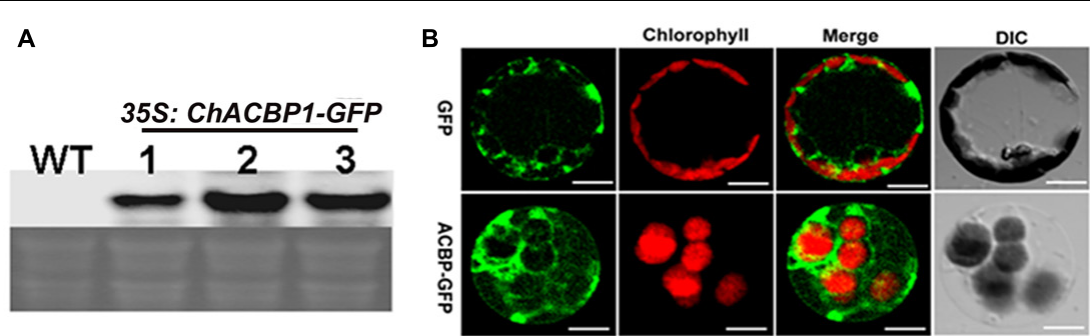

FIGURE 5 | Subcellular localization of ChACBP1 in Arabidopsis protoplasts. (A) Northern blot analysis with ChACBP1 cDNA probe in three independent pBI121-ChACBP1-GFP transgenic lines (lanes 1-3). WT, Wild type. (B) Confocal microscope images of protoplasts of Arabidopsis pBI121-ChACBP1-GFP line 2 indicating localization of ChACBP1-GFP in the cytosol. GFP empty vector is shown at the top. Bars $=20 \mu \mathrm{m}$.

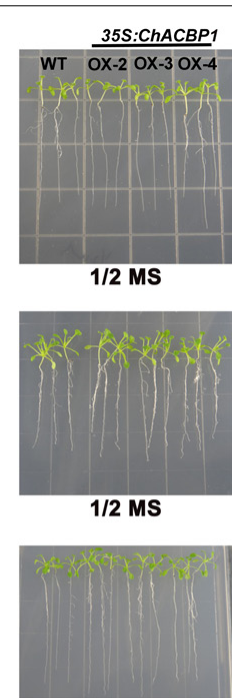

$1 / 2$ MS

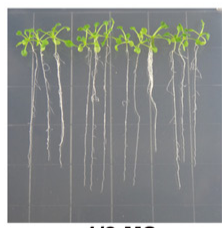

$1 / 2$ MS

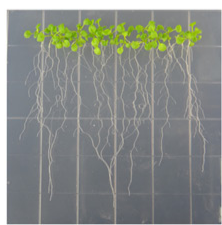

$1 / 2$ MS
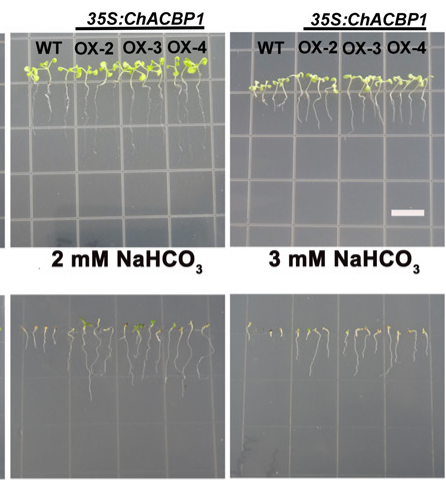

$125 \mathrm{mM} \mathrm{NaCl}$

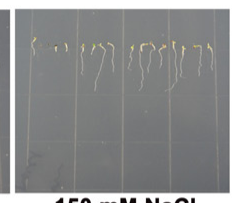

$150 \mathrm{mM} \mathrm{NaCl}$

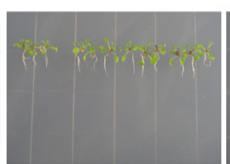

$2 \mathrm{mM} \mathrm{H}_{2} \mathrm{O}_{2}$

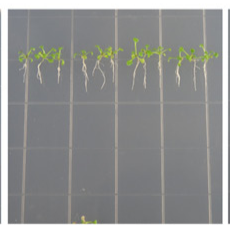

$50 \mu \mathrm{M} \mathrm{CuCl}_{2}$

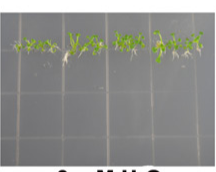

$3 \mathrm{mM} \mathrm{H}_{2} \mathrm{O}_{2}$

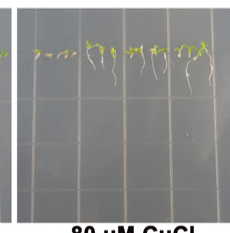

$80 \mu \mathrm{M} \mathrm{CuCl}_{2}$

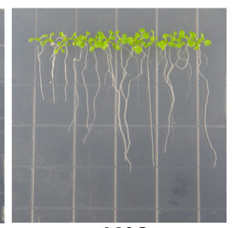

$16^{\circ} \mathrm{C}$

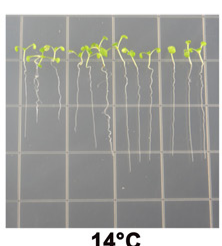

$14^{\circ} \mathrm{C}$

FIGURE 6 | Effects of abiotic stresses on root length in wild-type (WT) and ChACBP1-overexpressing transgenic plants. Seeds of WT and transgenic lines were grown on 1/2 MS medium supplemented with 2 and $3 \mathrm{mM}$ $\mathrm{NaHCO}_{3}, 125$ and $150 \mathrm{mM} \mathrm{NaCl}, 2$ and $3 \mathrm{mM} \mathrm{H}_{2} \mathrm{O}_{2}$, or 50 and $80 \mu \mathrm{M}$ $\mathrm{CuCl}_{2}$. Seedlings were grown for 7-14 days. For low temperature stress treatment, plants were grown at $16^{\circ} \mathrm{C}$ and $14^{\circ} \mathrm{C}$ for 30 days. Bars $=1 \mathrm{~cm}$.

and then cooling to $25^{\circ} \mathrm{C}$. Ionic leakage was detected using a conductivity meter (DDS-307, Leici Co., Ltd., Shanghai, China).

\section{RESULTS}

\section{Identification and Characterization of ChACBP}

The SAT Chlorella was isolated from extremely alkaline-saline soil $(\mathrm{pH}>10)$. The Chlorella cells were previously shown to tolerate $1 \mathrm{M} \mathrm{NaHCO}$ and $600 \mathrm{mM} \mathrm{NaCl}$ (Qiao et al., 2015). A cDNA library of Chlorella was expressed and screened in the InVSC1 strain of $S$. cerevisiae to identify potential genes involved in the strong stress tolerance of this microalga. Potential overexpression candidates were further verified under high $\mathrm{NaHCO}_{3}$ conditions (Supplementary Figure S1), and genes were isolated and sequenced (Supplementary Figure S2). The acyl-CoA-binding protein gene $(A C B P)$ was isolated from SAT Chlorella for the first time (white arrow), and was named $C h A C B P 1$. Yeast tolerance analyses showed that $C h A C B P$ expressing transformants grew better than the controls (YPD) under $35 \mathrm{mM} \mathrm{NaHCO}_{3}, 0.8 \mathrm{M} \mathrm{NaCl}, 3 \mathrm{mM} \mathrm{H}_{2} \mathrm{O}_{2}, 8 \mathrm{mM} \mathrm{CuCl}_{2}$, and at $10^{\circ} \mathrm{C}$ (Figure 1).

Analysis of the ChACBP1 sequence indicated that the ORF was 264 nucleotides long, and encoded a predicted protein of 87 amino acids. The cDNA sequence was found to contain a 57-bp 5'-untranslated region (UTR) and a 204-bp 3'-UTR. The amino acid sequence of ChACBP1 was found to share high identity with previously published ACBP sequences from other algae, plants, and animals. A comparison of the ACB domains of these ACBPs suggested conservation of the YKQA and KWDAW motifs (Figure 2A). In a neighbor-joining (NJ) tree of the ACBPs, ChACBP1 was closer to the ACBP of Chlorella variabilis (XP_005848979.1) than to the ACBPs of other species. In the tree, the SAT Chlorella first clustered with unicellular microalgae, then with plants and animals (Figure 2B), in agreement with the expected taxonomy. In a circular NJ tree, ChACBP1 was closer to AtACBP6 and OsACBP4 than to the ACBPs of Arabidopsis and rice (Figure 2C).

\section{ChACBP Interacted With Phospholipid $\mathrm{PC}$ in vitro}

The E. coli M15 cells transformed with the pQE30-ChACBP1 plasmid produced His-ChACBP1 fusion protein $(9.5 \mathrm{kDa})$ (Figure 3A, lane 1). Elution of the His-ChACBP1 fusion protein with $250 \mathrm{mM}$ imidazole gave a pure protein of the expected 

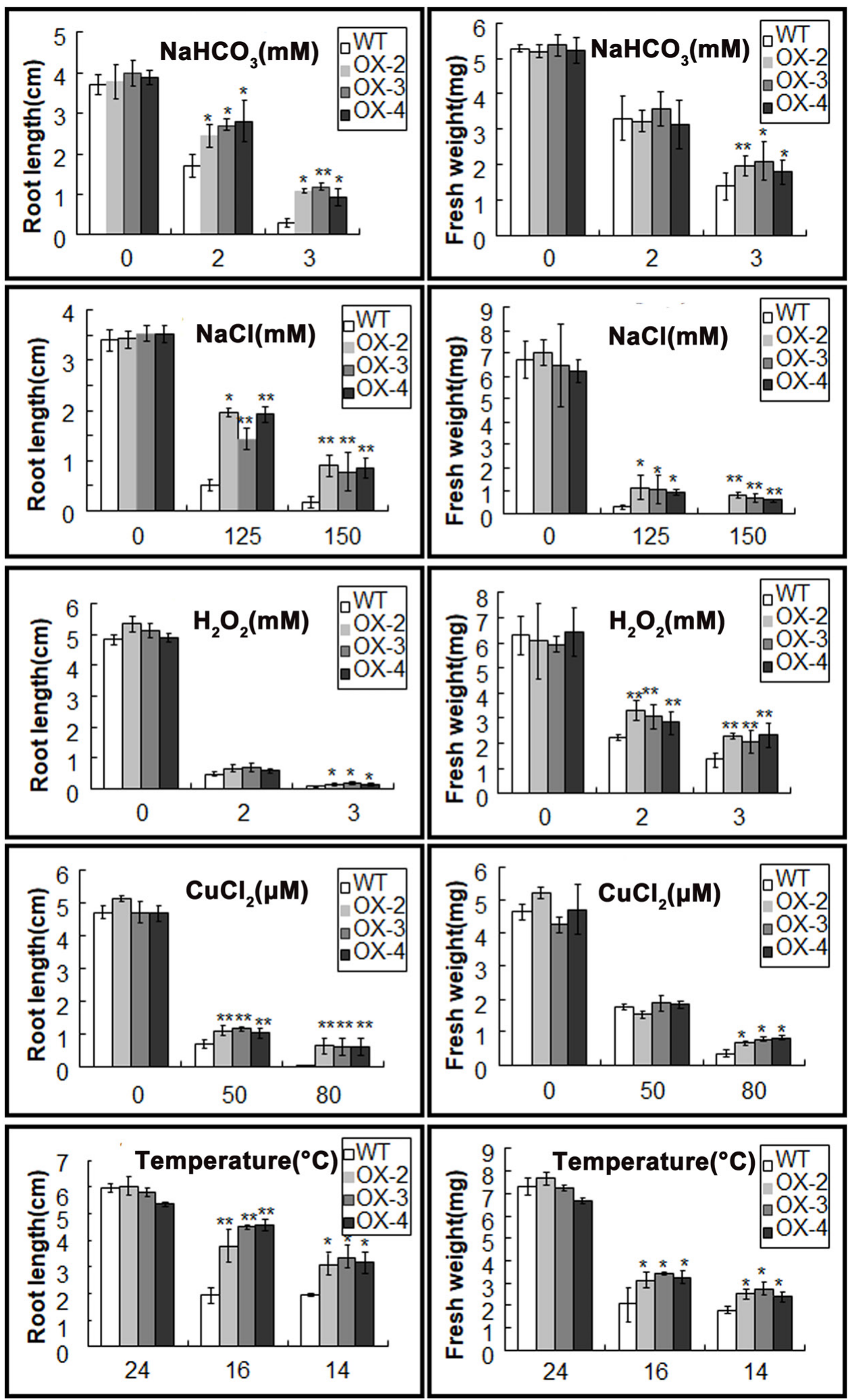

FIGURE 7 | Root length and fresh weight of wild-type (WT) and ChACBP1-overexpressing transgenic plants after indicated stress treatments. Values are mean \pm SE of four plants. Significant differences $(P<0.05)$ were determined by $t$-test. Asterisks indicate significant differences from $\mathrm{WT}\left({ }^{* *} P<0.01,{ }^{*} 0.01<P<0.05\right)$. 
size (Figure 3A, lane 2). Western blot analysis showed that the purified ChACBP1 protein was not degraded (Figure 3B). To detect the interaction between ChACBP1 and phospholipids (PC, PA, PS, PG, PE, DMPC), which influences abiotic stress tolerance, we tested the binding of purified ChACBP1 to various lipids. In the binding assays, ChACBP1 specifically bound PC, but not other lipids (Figure 3C). Further analyses showed that ChACBP1 was able to bind several species of PC (16:0-PC, 18:0-PC, and 18:1-PC) (Figure 3D).

\section{Induction of ChACBP1 Expression by Multiple Abiotic Stresses}

Northern blot analyses were used to examine the response of $C h A C B P 1$ expression to various abiotic stresses. Analyses of total RNA extracted from SAT Chlorella exposed to $\mathrm{NaHCO}_{3}, \mathrm{NaCl}$, $\mathrm{H}_{2} \mathrm{O}_{2}, \mathrm{CuCl}_{2}$, and $4^{\circ} \mathrm{C}$ for $0,3,6,12,24$, and $48 \mathrm{~h}$ indicated that the ChACBP1 mRNA levels increased in the $200 \mathrm{mM} \mathrm{NaHCO}_{3}$ treatment from 3 to $48 \mathrm{~h}$, compared with the control $(0 \mathrm{~h})$. ChACBP1 mRNA began to increase after $3 \mathrm{~h}$ in the $200 \mathrm{mM}$ $\mathrm{NaCl}$ treatment and peaked after $24 \mathrm{~h}$ of treatment. ChACBP gene expression was induced at $12 \mathrm{~h}$ of the $2 \mathrm{mM} \mathrm{H}_{2} \mathrm{O}_{2}$ treatment and its expression level peaked at $48 \mathrm{~h}$. The expression level of $C h A C B P 1$ was higher after $3 \mathrm{~h}$ of the $100 \mu \mathrm{M} \mathrm{CuCl}_{2}$ treatment than in the control. Subsequently, its expression level increased gradually at 6,12 , and $24 \mathrm{~h}$ of the $100 \mu \mathrm{M} \mathrm{CuCl}_{2}$ treatment, but was similar to the control after $48 \mathrm{~h}$. The expression level of $C h A C B P 1$ began to increase after $3 \mathrm{~h}$ at $4^{\circ} \mathrm{C}$ and peaked at $48 \mathrm{~h}$ (Figure 4A). The level of ChACBP1 expression was affected by the concentration as well as the duration of the stress elicitors.

Northern blot analyses were conducted using total RNA extracted from SAT Chlorella exposed to different concentrations of $\mathrm{NaHCO}_{3}, \mathrm{NaCl}, \mathrm{H}_{2} \mathrm{O}_{2}$, and $\mathrm{CuCl}_{2}$, and different temperatures for $6 \mathrm{~h}$. At this time point, ChACBP1 mRNA levels were slightly higher in the $50 \mathrm{mM} \mathrm{NaHCO}$ treatment than in the control and were higher in the treatments with higher $\mathrm{NaHCO}_{3}$ concentrations. The peak expression level of ChACBP1 among the $\mathrm{NaHCO}_{3}$ treatments was in the $300 \mathrm{mM} \mathrm{NaHCO}$ treatment. The highest $C h A C B P 1$ expression level among the $\mathrm{NaCl}$ treatments was in the $300 \mathrm{mM} \mathrm{NaCl}$ treatment. The expression level of ChACBP1 was slightly increased in the $1 \mathrm{mM}$ $\mathrm{H}_{2} \mathrm{O}_{2}$ treatment, compared with the control, and its highest expression level among the $\mathrm{H}_{2} \mathrm{O}_{2}$ treatments was in the $5 \mathrm{mM}$ $\mathrm{H}_{2} \mathrm{O}_{2}$ treatment. The expression of ChACBP1 was induced by $50 \mu \mathrm{M} \mathrm{CuCl}_{2}$ and its expression level gradually increased as the concentration increased to $300 \mu \mathrm{M} \mathrm{CuCl}_{2}$. The expression levels of ChACBP1 in the $18^{\circ} \mathrm{C}, 16^{\circ} \mathrm{C}$, and $14^{\circ} \mathrm{C}$ treatments were not significantly different from that in the control $\left(24^{\circ} \mathrm{C}\right)$, but were increased in the $10^{\circ} \mathrm{C}$ treatment to a level similar to that measured at $4^{\circ} \mathrm{C}$ (Figure $4 \mathrm{~B}$ ). These data suggested that the expression of $C h A C B P 1$ was induced by $\mathrm{NaHCO}_{3}, \mathrm{NaCl}, \mathrm{H}_{2} \mathrm{O}_{2}, \mathrm{CuCl}_{2}$, and low temperature stresses.

\section{ChACBP1 Localizes to the Cytosol}

The expression of ChACBP1-GFP mRNA in three independent pBI121-ChACBP1-GFP transgenic Arabidopsis lines was detected by Northern blot analysis using a ChACBP1 cDNA probe
(Figure 5A). Analyses of the shoots of line 2 expressing pBI121ChACBP1-GFP revealed that the GFP signal was localized in the cytosol. The GFP control was also expressed in the cytosol (Figure 5B).

\section{Generation of ChACBP1 Transgenic Arabidopsis}

To test whether ChACBP1 overexpression enhanced abiotic tolerance, the ChACBP1 full-length cDNA was expressed in the Arabidopsis by an Agrobacterium-mediated method. Four independent ChACBP1-overexpressing lines (OX-1, OX-2, OX3 , and OX-4) were identified by Northern blot analysis using ChACBP1 mRNA. A Southern blot analysis indicated that OX2, OX-3, and OX-4 had one or two gene copies (Supplementary Figure S3).

\section{Overexpression of ChACBP1 in Arabidopsis Enhanced Tolerance to Multiple Abiotic Stresses}

When grown on $1 / 2 \mathrm{MS}$ medium, the three transgenic lines (OX-2, OX-3, and OX-4) over-expressing ChACBP1 were not noticeably different from WT (Figures 6, 7). Under 2 and $3 \mathrm{mM}$ $\mathrm{NaHCO}_{3}$ treatment, root growth was significantly enhanced in ChACBP1-overexpressing Arabidopsis lines, compared with WT $(P<0.05)$. The entire seedling fresh weight was greater in the overexpressing lines than in the WT only in the $3 \mathrm{mM} \mathrm{NaHCO}_{3}$ treatment $(P<0.05$; Figure 7$)$. In the presence of 125 and $150 \mathrm{mM} \mathrm{NaCl}$, the root length and fresh weight were higher in the overexpressing lines than in WT $(P<0.05$; Figures 6, $7)$. When grown under oxidative stress $\left(\mathrm{H}_{2} \mathrm{O}_{2}\right)$, root length was not notably different between the overexpressing lines and WT. However, the leaves of the overexpressing lines grew better than did those of WT $(P<0.05$; Figures 6,7$)$. The fresh weights of the overexpressing lines were higher than those of WT in the 2 and $3 \mathrm{mM} \mathrm{H}_{2} \mathrm{O}_{2}$ treatments $(P<0.05$; Figure 7$)$. When the plants were exposed to $\mathrm{CuCl}_{2}$ and low temperature stresses, root lengths and fresh weights were higher in the overexpressing lines than in the WT $(P<0.05$; Figures 6, 7).

To evaluate membrane injury after different stress treatments, electrolyte leakage was measured in 2-week-old seedlings from WT and ChACBP1-overexpressing plants treated with different concentrations of $\mathrm{NaHCO}_{3}, \mathrm{NaCl}, \mathrm{H}_{2} \mathrm{O}_{2}$, and $\mathrm{CuCl}_{2}$, and different temperatures. The results showed that ionic leakage was not obviously different between WT and overexpressing lines in the $1 \mathrm{mM} \mathrm{NaHCO} 3$ treatment, but was significantly higher in overexpressing lines than in WT plants in the 3 to $10 \mathrm{mM}$ $\mathrm{NaHCO}_{3}$ treatments $(P<0.05$; Figure 8A). In comparison, the ionic leakage in $C h A C B P 1$-overexpressing seedlings was significantly lower $(P<0.05)$ than that in WT in the 100 , 125,150 , and $175 \mathrm{mM} \mathrm{NaCl}$ treatments. There was no obvious difference in ionic leakage between WT and overexpression lines in the $200 \mathrm{mM} \mathrm{NaCl}$ treatment (Figure 8B). The ionic leakage was significantly lower $(P<0.05)$ in $C h A C B P 1$-overexpressing plants than in WT plants in all the temperature treatments $\left(18^{\circ} \mathrm{C}, 16^{\circ} \mathrm{C}, 14^{\circ} \mathrm{C}, 12^{\circ} \mathrm{C}\right.$, and $\left.10^{\circ} \mathrm{C}\right)(P<0.05$; Figure $8 \mathrm{E})$. In the presence $\mathrm{H}_{2} \mathrm{O}_{2}$ and $\mathrm{CuCl}_{2}$, ionic leakage was lower in 


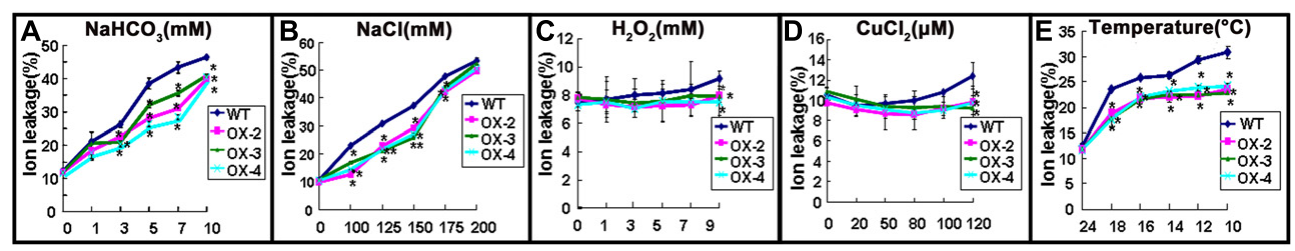

FIGURE 8 | Electrolyte leakage of wild-type (WT) and ChACBP1-overexpressing (OX-2, OX-3, and OX-4) plants after $24 \mathrm{~h}$ of treatment with $\mathrm{NaHCO}_{3}(0,1,3,5,7$, and $10 \mathrm{mM}$ ) (A), $\mathrm{NaCl}(0,100,125,150,175$, and $200 \mathrm{mM})$ (B), $\mathrm{H}_{2} \mathrm{O}_{2}(0,1,3,5,7$, and $9 \mathrm{mM})$ (C), $\mathrm{CuCl}_{2}(0,20,50,80,100$, and $120 \mu \mathrm{M})$ (D), or low temperature $\left(24^{\circ} \mathrm{C}, 18^{\circ} \mathrm{C}, 16^{\circ} \mathrm{C}, 14^{\circ} \mathrm{C}, 12^{\circ} \mathrm{C}\right.$, and $\left.10^{\circ} \mathrm{C}\right)(\mathbf{E})$. Values are means $\pm S D(n=3)$ from three independent experiments. Asterisks indicate significant differences from WT $(* * P<0.01, * 0.01<P<0.05)$.

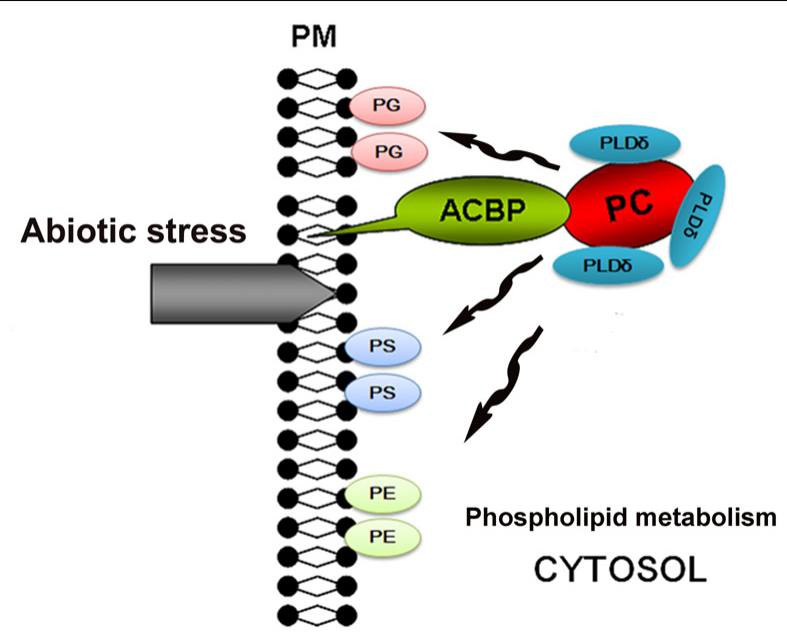

FIGURE 9 | Hypothetical model for stress tolerance function of Chlorella ACBP. ACBP, acyl-CoA-binding protein; PC, phosphatidylcholine; PG, phosphatidylglycerol; PS, phosphatidyl-serine; PE, phosphatidylethanolamine; PLD $\delta$, phospholipases D $\delta$; PM, plasma membrane.

the overexpressing plants than in the WT only at the higher concentrations ( $9 \mathrm{mM} \mathrm{H}_{2} \mathrm{O}_{2}$ and $120 \mu \mathrm{M} \mathrm{CuCl}_{2}$, respectively) $(P<0.05$; Figures 8C,D).

\section{DISCUSSION}

China has 99.13 million hectares of saline-alkali soil, which accounts for $10 \%$ of the world's saline-alkali land. The alkalinity in these regions is generally high, resulting in oxidative and salt stress. Drought stress is also common in these environments. As a result, few plants can survive under such conditions. In recent years, the area of saline-alkali soil has gradually increased as a result of environmental changes and human activities (Wang et al., 2011; Qiao et al., 2015). These changes have resulted in severe losses in agricultural production. We previously reported that Chlorella JB6 can survive in extreme saline-alkali soil with $\mathrm{pH}>9.5$ (Qiao et al., 2015). Therefore, this species may be a useful resource for plant genetic engineering.

We isolated ChACBP1 by screening a cDNA library of SAT Chlorella JB6. The full-length protein sequence was found to be homologous with the amino acid sequences of the small ACBPs from other species used to construct the NJ tree. Some functionally critical motifs in ACBPs have been relatively well conserved throughout evolution. However, there were some differences between the $\mathrm{N}$-terminal or $\mathrm{C}$-terminal regions of ChACBP1 and those of ACBPs in other species (Figure 2), suggesting that the function of ChACBP1 may be slightly different from that of ACBPs in other species. The YKQA and KWDAW motifs in the ACB conserved domain are considered to be essential for binding PC (Zhang et al., 2008). An evolutionary analysis of the Chlorella, Arabidopsis, and rice ACBP families indicated that ChACBP1 might be close to AtACBP6 and OsACBP4 in its structure and function. Therefore, the $A C B P$ gene in Chlorella was considered to encode an acyl-CoA-binding protein. We tested the binding of ChACBP1 to phospholipids in filter-binding assays and observed that ChACBP1 bound PC (Figure 3), similar to the lipid-binding properties of AtACBP6 (Chen et al., 2008). It was hinted that ChACBP1 might transport multiple PCs associated with phospholipid metabolism. Phospholipids are the main components of cell membranes. In this study, the ion leakage (membrane stability index) of ChACBP1-overexpressing Arabidopsis was lower than that of WT under different stresses (Figure 8). This result suggested that ACBP may play a role in protecting the plasma membrane.

Our results showed that the Chlorella ACBP1 gene was induced by $\mathrm{NaHCO}_{3}, \mathrm{NaCl}, \mathrm{H}_{2} \mathrm{O}_{2}, \mathrm{CuCl}_{2}$, and low temperatures, and that overexpression of ChACBP1 in yeast and Arabidopsis improved stress tolerance compared with that of their WT controls (Figures 1, 6). In cotton, GhACBP3 and GhACBP6 were found to be up-regulated under high salinity stress (Qin et al., 2016). In Arabidopsis, ACBP2-overexpressing lines showed enhanced tolerance to $\mathrm{H}_{2} \mathrm{O}_{2}$ (Gao et al., 2009), and both AtACBP1- and AtACBP2-overexpressors displayed enhanced tolerance to heavy metals ( $\mathrm{Pb}$ or $\mathrm{Cd}$ ) (Xiao et al., 2008; Gao et al., 2009). The expression level of AtACBP6 was found to be upregulated by cold treatment (Chen et al., 2008). In the present study, ChACBP1 was isolated from a cDNA library expressed in yeast grown under $\mathrm{NaHCO}_{3}$ stress, and overexpression of ChACBP1 in yeast and Arabidopsis improved their tolerance to $\mathrm{NaHCO}_{3}$ (Figures 1, 7). Because $\mathrm{NaHCO}_{3}$ treatment likely leads to other stresses, such as salinity, alkalinity, oxidative, and drought stresses, it is not surprising that ChACBP1 can confer tolerance to multiple abiotic stresses. However, the mechanism of ChACBP1 tolerance is still unclear. 
Overexpression of ACBP6 in Arabidopsis was shown to enhance the activities of phospholipase $\mathrm{D} \delta(\mathrm{PLD} \delta)$, which in turn enhanced cold tolerance by stabilizing the membrane skeleton (Chen et al., 2008). PLD $\delta$ can convert PC into PG, PS, and PE, all of which stabilize the cell membrane. Therefore, we propose a model in which exposure of the plasma membrane to abiotic stresses induces the expression of $C h A C B P 1$, and the subsequent increase in ChACBP1 protein leads to increased binding and transport of PC to the plasma membrane from within the cytosol. Hence, the increase in PG, PS, and PE contents increases the stability of the cell membrane (Figure 9). However, this model is still hypothetical. Like ACBPs from higher plants, ChACBP1 conferred tolerance to various abiotic stresses. The proposal that ChACBP1 mediates plant abiotic stress adaptation through phospholipid metabolism should be tested experimentally in further studies.

\section{ETHICS STATEMENT}

This study was approved by the ethics committee of Zhejiang Agriculture and Forestry University.

\section{REFERENCES}

Aznar-Moreno, J. A., Venegas-Caleron, M., Du, Z. Y., Garces, R., Tanner, J. A., Chye, M. L., et al. (2016). Characterization of a small acyl-CoA-binding protein (ACBP) from Helianthus annuus L. and its binding affinities. Plant Physiol. Biochem. 102, 141-150. doi: 10.1016/j.plaphy.2016.02.025

Bold, H. C., and Wynne, M. J. (1978). Introduction to the Algae. Englewood, NJ: Prentice Hall, 720.

Brown, A. P., Johnson, P., Rawsthorne, S., and Hills, M. J. (1998). Expression and properties of acyl-CoA binding protein from Brassica napus. Plant Physiol. Biochem. 36, 629-635. doi: 10.1016/S0981-9428(98)80011-9

Chen, Q. F., Xiao, S., and Chye, M. L. (2008). Overexpression of the Arabidopsis 10-kilodalton acyl-coenzyme a-binding protein ACBP6 enhances freezing tolerance. Plant Physiol. 148, 304-315. doi: 10.1104/pp.108.123331

Chen, Q. F., Xiao, S., Qi, W. Q., Mishra, G., Ma, J. Y., Wang, M. F., et al. (2010). The Arabidopsis acbplacbp2 double mutant lacking the acyl-CoA-binding proteins ACBP1 and ACBP2 is embryo lethal. New Phytol. 186, 843-855. doi: 10.1111/j. 1469-8137.2010.03231.x

Clough, S. J., and Bent, A. F. (1998). Floral dip: a simplified method for Agrobacterium mediated transformation of Arabidopsis thaliana. Plant J. 16, 735-743. doi: 10.1046/j.1365-313x.1998.00343.x

Du, Z. Y., Chen, M. X., Chen, Q. F., Gu, J. D., and Chye, M. L. (2015). Expression of Arabidopsis acyl-CoA-binding proteins AtACBP1 and AtACBP4 confers $\mathrm{Pb}$ (II) accumulation in Brassica juncea roots. Plant Cell Environ. 38, 101-117. doi: $10.1111 /$ pce. 12382

Du, Z. Y., Chen, M. X., Chen, Q. F., Xiao, S., and Chye, M. L. (2013). Overexpression of Arabidopsis acyl-CoA-binding protein ACBP2 enhances drought tolerance. Plant Cell Environ. 36, 300-314. doi: 10.1111/j.1365-3040. 2012.02574.x

Du, Z. Y., Xiao, S., Chen, Q. F., and Chye, M. L. (2010). Depletion of the membraneassociated acyl-Coenzyme A-binding protein ACBP1 enhances the ability of cold acclimation in Arabidopsis. Plant Physiol. 152, 1585-1597. doi: 10.1104/ pp.109.147066

Engeseth, N. J., Pacovsky, R. S., Newman, T., and Ohlrogge, J. B. (1996). Characterization of an acyl-CoA-binding protein from Arabidopsis thaliana. Arch. Biochem. Biophys. 331, 55-62. doi: 10.1006/abbi.1996.0282

Gao, W., Li, H. Y., Xiao, S., and Chye, M. L. (2010). Acyl-CoA-binding protein 2 binds lysophospholipase 2 and lysoPC to promote tolerance to cadmiuminduced oxidative stress in transgenic Arabidopsis. Plant J. 62, 989-1003. doi: 10.1111/j.1365-313X.2010.04209.x

\section{AUTHOR CONTRIBUTIONS}

SL and TT conceived and designed the research. KQ and MW conducted the experiments. KQ analyzed the data and wrote the manuscript. All authors revised and approved the manuscript.

\section{FUNDING}

This work was supported by Special Fund for Forest Scientific Research in the Public Welfare (201404220), Program for Changjiang Scholars and Innovative Research Team in University (PCSIRT) (IRT_17R99), and Fundamental Research Funds for the Central Universities (252016AA56).

\section{SUPPLEMENTARY MATERIAL}

The Supplementary Material for this article can be found online at: https://www.frontiersin.org/articles/10.3389/fpls.2018.01772/ full\#supplementary-material

Gao, W., Xiao, S., Li, H. Y., Tsao, S. W., and Chye, M. L. (2009). Arabidopsis thaliana acyl-CoA-binding protein ACBP2 interacts with heavy-metal-binding farnesylated protein ATFP6. New Phytol. 181, 89-102. doi: 10.1111/j.1469-8137. 2008.02631.x

Guo, R., Shi, L. X., Yang, C. W., Yan, C. R., Zhong, X. L., Liu, Q., et al. (2016). Comparison of ionomic and metabolites response under alkali stress in old and young leaves of cotton (Gossypium hirsutum 1.) seedlings. Front. Plant Sci. 7:1785. doi: 10.3389/fpls.2016.01785

Hills, M. J., Dann, R., Lydiate, D., and Sharpe, A. (1994). Molecular cloning of a cDNA from Brassica napus L. for a homologue of acylCoA-binding protein. Plant Mol. Biol. 25, 917-920. doi: 10.1007/BF0002 8886

Mandrupl, S., Hummell, R., Ravn, S., Jensen, G., Andreasen, P. H., Gregersen, N., et al. (1992). Acyl-CoA-binding protein/diazepam-binding inhibitor gene and pseudogenes: a typical housekeeping gene family. J. Mol. Biol. 228, 1011-1022. doi: 10.1016/0022-2836(92)90888-Q

Metzner, M., Ruecknagel, K. P., Knudsen, J., Kuellertz, G., Mueller-Uri, F., and Diettrich, B. (2000). Isolation and characterization of two acyl-CoA-binding proteins from proembryogenic masses of Digitalis lanata Ehrh. Planta 210, 683-685. doi: 10.1007/s004250050060

Qiao, K., Takano, T., and Liu, S. K. (2015). Discovery of two novel highly tolerant NaHCO3 Trebouxiophytes: identification and characterization of microalgae from extreme saline-alkali soil. Algal Res. 9, 245-253. doi: 10.1016/j.algal.2015. 03.023

Qin, P. F., Shang, X. G., Song, J., and Guo, W. Z. (2016). Genome-wide identification of Acyl-CoA-binding protein (ACBP) gene family and their functional analysis in abiotic stress tolerance in cotton. Acta Agron. Sin. 42, 1577-1591. doi: 10.3724/SP.J.1006.2016.01577

Reddy, A. S., Ranganathan, B., Haisler, R. M., and Swize, M. A. (1996). A cDNA encoding acyl-CoA-binding protein from cotton. Plant Physiol. 111:348.

Sheen, J. (2002). A Transient Expression Assay Using Arabidopsis MesophyII Protoplasts. Available at: http://genetics.mgh.harvard.edu/sheenweb/

Shi, W., Takano, T., and Liu, S. K. (2012). Isolation and characterization of novel bacterial taxa from extreme alkali-saline soil. World J. Microb. Biotechnol. 28, 2147-2157. doi: 10.1007/s11274-012-1020-7

Song, T. T., Xu, H. H., Sun, N., Jiang, L., Tian, P., Yong, Y. Y., et al. (2017). Metabolomic analysis of alfalfa (Medicago sativa L.) root-symbiotic rhizobia responses under alkali stress. Front. Plant Sci. 8:1208. doi: 10.3389/fpls.2017. 01208 
Suzui, N., Nakamura, S., Fujiwara, T., Hayashi, H., and Yoneyama, T. (2006). A putative acyl-CoA-binding protein is a major phloem sap protein in rice (Oryza sativa L.). J. Exp. Bot. 57, 2571-2576. doi: 10.1093/jxb/erl021

Wang, J., Shi, W., Takano, T., and Liu, S. K. (2011). Purification and resistance analysis of algae of soda soil in northeast China. Mol. Soil Biol. $3,1-4$.

Xiao, S., and Chye, M. L. (2009). An Arabidopsis family of six acyl-CoA-binding proteins has three cytosolic members. Plant Physiol. Biochem. 47, 479-484. doi: 10.1016/j.plaphy.2008.12.002

Xiao, S., and Chye, M. L. (2011). New roles for acyl-CoA-binding proteins (ACBPs) in plant development, stress responses and lipid metabolism. Prog. Lipid Res. 50, 141-151. doi: 10.1016/j.plipres.2010.11.002

Xiao, S., Gao, W., Chen, Q. F., Chan, S. W., Zheng, S. X., Ma, J. Y., et al. (2011). Overexpression of Arabidopsis acyl-CoA-binding protein ACBP3 promotes starvation-induced and age-dependent leaf senescence. Plant Cell 22, 14631482. doi: 10.1105/tpc.110.075333

Xiao, S., Gao, W., Chen, Q. F., Ramalingam, S., and Chye, M. L. (2008). Overexpression of membrane-associated acyl-CoA-binding protein ACBP1 enhances lead tolerance in Arabidopsis. Plant J. 54, 141-151. doi: 10.1111/j. 1365-313X.2008.03402.x
Ye, Z. W., Lung, S. C., Hu, T. H., Chen, Q. F., Suen, Y. L., Wang, M. F., et al. (2016). Arabidopsis acyl-CoA-binding protein ACBP6 localizes in the phloem and affects jasmonate composition. Plant Mol. Biol. 92, 717-730. doi: 10.1007/ s11103-016-0541-0

Zhang, X. X., Liu, S. K., and Takano, T. (2008). Two cysteine proteinase inhibitors from Arabidopsis thaliana, AtCYSa and AtCYSb, increasing the salt, drought, oxidation and cold tolerance. Plant Mol. Biol. 68, 131-143. doi: 10.1007/s11103008-9357-x

Conflict of Interest Statement: The authors declare that the research was conducted in the absence of any commercial or financial relationships that could be construed as a potential conflict of interest.

Copyright (c) 2018 Qiao, Wang, Takano and Liu. This is an open-access article distributed under the terms of the Creative Commons Attribution License (CC BY). The use, distribution or reproduction in other forums is permitted, provided the original author(s) and the copyright owner(s) are credited and that the original publication in this journal is cited, in accordance with accepted academic practice. No use, distribution or reproduction is permitted which does not comply with these terms. 